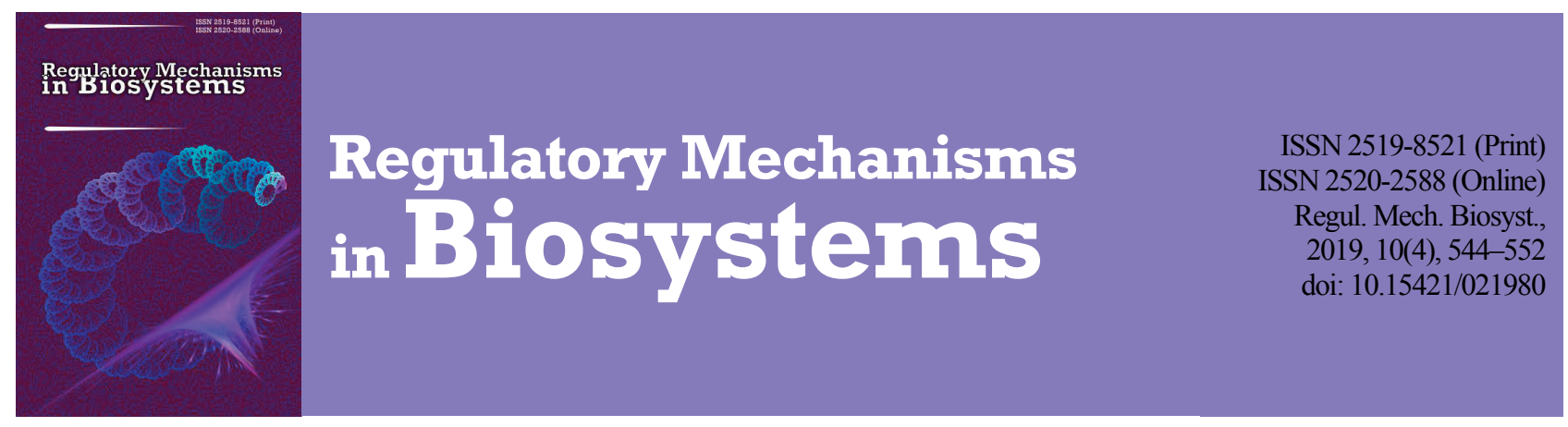

\title{
Evaluation of effects of selenium nanoparticles on Bacillus subtilis
}

\author{
N. O. Tymoshok*, M. S. Kharchuk*, V. G. Kaplunenko*, V. S. Bityutskyy**, \\ S. I. Tsekhmistrenko**, O. S. Tsekhmistrenko**, M. Y. Spivak*, O. M. Melnichenko** \\ *D. K. Zabolotny Institute of Microbiology and Virology of the National Academy of Sciences of Ukraine, Kyiv, Ukraine \\ **BilaTserkva National Agrarian University, Bila Tserkva, Ukraine
}

Article info

Received 11.10.2019 Received in revised form Accepted 07.11.2019

D. K. Zabolotny Institute of Microbiology and Virolog of the National Academy of Sciences of Ukraine Zabolotny av., 154, Kyiv, 03187, Ukraine. Tel.: +38-066-482-67-61. E-mail:n_timoshok@ukr.net

Bila Tserkva National Agrarian University, Bila Tserkva, 09100, Ukraine. Tel.: +38-068-034-48-48 E-mail:voseb@ukr.net 05.11 .2019 Soborna ploshcha, 8/1,

Tymoshok, N. O., Kharchuk, M. S., Kaplunenko, V. G., Bityutskyy, V. S., Tsekhmistrenko, S. I., Tsekhmistrenko, O. S., Spivak, M. Y., \& Melnichenko, O. M. (2019). Evaluation of effects of selenium nanoparticles on Bacillus subtilis. Regulatory Mechanisms in Biosystems, 10(4), 544-552. doi:10.15421/021980

The present study was performed to characterize of selenium nanoparticles (Nano-Se) which were synthesized by pulsed laser ablation in liquids to obtain the aqueous selenium citrate solution. The study was conducted using bacteriological and electronicmicroscopic methods. Transmission electron microscopy (TEM) and spectroscopy analyses demonstrated that nano-selenium particles obtained by the method of selenium ablation had the size of 4-8 nm. UV-Visible Spectrum colloidal solution Nano-Se exhibited absorption maxima at $210 \mathrm{~nm}$. To clarify some effects of the action of Nano-Se on Bacillus subtilis, we investigated the interaction of Nano-Se with B. subtilis IMV B-7392 before and after incubation with Nano-Se, examining TEM images. It has been shown that exposure to B. subtilis IMV B-7392 in the presence of Nano-Se is accompanied by the rapid uptake of Nano-Se by bacterial culture. TEM analysis found that the electron-dense Nano-Se particles were located in the intracellular spaces of B. subtilis IMV B7392. That does not lead to changes in cultural and morphological characteristics of B. subtilis IMV B-7392. Using TEM, it has been shown that penetration of nanoparticles in the internal compartments is accompanied with transient porosity of the cell membrane of B. subtilis IMV B-7392 without rupturing it. The effective concentration of Nano-Se $0.2 \times 10^{-3} \mathrm{mg} / \mathrm{mL}$ was found to increase the yield of biologically active substances of $B$. subtilis. In order to create probiotic nano-selenium containing products, the nutrient medium of $B$. subtilis IMV B-7392 was enriched with Nano-Se at $0.2 \times 10^{-3} \mathrm{mg} / \mathrm{mL}$. It was found that particles Nano-Se are non-toxic to the culture and did not exhibit bactericidal or bacteriostatic effects. The experimentally demonstrated ability of $B$. subtilis to absorb selenium nanoparticles has opened up the possibility of using Nano-Se as suitable drug carriers.

Keywords: TEM analysis; nifS (nitrogenfixation) like gene; system of selenite detoxification; uptake of Nano-Se; probiotic.

\section{Introduction}

Due to the phenomenon of dimensional effect of their size nanomaterials have unique new properties that distinguish them from macro- and microparticles (Pouri et al., 2017; Naito et al., 2018). A significant increase in the surface-to-volume ratio leads to an increase in the function and reactivity of atoms located on the surface of nanoparticles. Among nanoparticles, metal nanoparticles attract great attention due to their catalytic, absorbent, optical properties and especially biological and medical methods of application (Bityutskyy et al., 2017; Naito et al., 2018; Tsekhmistrenko et al., 2018).

Over the past decades, research on the development of environmentally friendly processes for the production of biogenic metal nanoparticles, metal oxides and metalloids, including the redox active nano-selenium metalloid, received great attention as an alternative to time-consuming physicochemical methods, which are expensive and environmentally unacceptable due to the effects of organic solvents used for the synthesis of nanostructures (Pouri et al., 2017; Tsekhmistrenko et al., 2017).

In the presence of high metal concentrations microorganisms have developed specific adaptation mechanisms to reduce their toxicity, which included a change in the chemical nature of the metal. This leads to the formation of nanoparticles of the corresponding metal, which are a "byproduct" of the adaptive protection mechanism. Such "green" synthesis can be used as an alternative to the physical and chemical methods used to obtaining them (Pantidos \& Horsfall, 2014). The development of selenium-enriched probiotics has attracted tremendous interest because of the properties of selenium, (Se) which is included in at least 30 selenoproteins which support the activity of immune system and influence life expectancy. Selenium is a constituent of glutathione peroxidase (Burk, 1983), thyroid reductase (Mehdi et al., 2013), and selenocysteine of the 21st amino acid, which is involved in the biosynthesis of cysteine (Cys) and oxidation-reducing reactions, both in humans and bacteria.

However, there is a narrow range between the concentration of Se, at which it is beneficial, and that at which it has a toxic effect. The daily norm of Se, in the composition of selenocysteine, is $60 \mu \mathrm{g} /$ day for women and $70 \mu \mathrm{g} /$ day for men (Mehdi et al., 2013). In high concentrations (900 $\mu \mathrm{g} /$ day), selenium becomes extremely toxic (Böck et al., 1991). Selenium preparations in the form of L-selenomethionine become rapidly and completely absorbed by the organism, causing minimal side effects. Selenomethionine (Se-Met) takes the position of methionine in various proteins and provides regulation of the endocrine system, though Se-Met is not synthesized in the body (Schrauzer, 2003). That is why great attention is currently being paid to bioavailable forms of Se, including bioselenium which can be obtained using probiotic microorganisms.

B. subtilis attract much attention in the biomedical field and is used as an approach of detoxification of selenates in selenite, and reduction of selenium and the formation of elemental selenium $(\mathrm{SeO})$ or selenium nanoparticles (SeNPs) (Garbisu et al., 1996; Garbisu et al., 1999; Yu et al., 2018). B. subtilis is capable of carrying out oxidization/reduction reactions due to specific selenoenzyme - selenium methyltransferase and selenium oxide reductase, which have some homology with arsenate reductase of B. subtilis 168 (Stolz \& Oremland, 1999; Stolz et al., 2006). In addition, 
bacteria of $B$. subtilis species were shown to have NifS (nitrogenfixation) homologues of the Azotobacter vinelandii (Sun \& Setlow, 1993) system. NifS homologues play a general role in the mobilization of sulfur to synthesize the "nitrogen-fixing" system of Fe-S clusters that support intracellular redox homeostasis (Ayala-Castro et al., 2008). The nifS gene clusters from prokaryotes and eukaryotes exhibited a high degree of sequencing, although genes have a variety of functions. The presence of a nifS-like gene was found for bacteria of the species Lactobacillus delbrueckii bulgaricus. Thus, the product of the nifS-like $L . d$. bulgaricus gene, according to the sequences, was $33 \%$ homologous to the product of the nifS gene B. subtilis (Leong-Morgenthaler et al., 1994). The presence of the nifS-like gene of $L$. d. bulgaricus is of interest because the NitFS protein $A$. vinelandii, together with selenocysteine, is part of the $\mathrm{Se}(0)$ generating system which can replace selenide for biosynthesis of selenophosphate in vitro (Stadtman, 1974; Lacourciere \& Stadtman, 2000). Thus, the research has shown that $L$. d. bulgaricus LB-12 displayed the property of concentrating Se intracellularly in the form of nanoparticles (Palomo-Siguero \& Madrid, 2017). The presence of nitrogen-fixing nifS-like genes in $A$. vinelandii, and nitrogen non-fixing nifS-like genes in B. subtilis, L. bulgaricus and $S$. cerevisiae suggests that the products of the nifS gene have been preserved during evolution. Some NifS homologues were shown to catalyze the same type of reaction, that is, the removal of sulfur or selenium atom from L-cysteine or L-selenocysteine to produce L-alanine. That is, NifS proteins act on both L-cysteine and L-selenocysteine (Lacourciere \& Stadtman, 1998).

At the same time, several enzymes involved in sulfur metabolism also affect selenium analogues of substrates (Sun \& Setlow, 1993). Thus, among the NifS proteins, including selenocysteine lyase (SCL) 1 (EC 4.4.1.16) and cysteine desulfurase, particularly SCL is considered as an enzyme that exclusively decomposes L-selenocysteine. The studies revealed the role of selenocysteine (Se-Cys) in the synthesis of specific selenium enzymes (Böck, 2001). Thus, selenoproteins, such as formate dehydrogenase from Escherichia coli, contain residues of selenocysteine (Zinoni et al., 1986). Selenocysteyl-tRNASec is necessary for the biosynthesis of these selenoproteins (Forchhammer et al., 1989).

Selenophosphate is a highly reactive selenium-containing compound and functions as a donor of selenium for the production of selenocysteyltRNASec (Lee et al., 1989). Selenophosphate is synthesized from selenide and ATP, the reaction catalyst is selenophosphatesynthetase (Mullins et al., 1997). Recently Lacourciere \& Stadtman (1998) have found that the replacement of selenide with NifS and L-selenocysteine in the analysis of selenophosphatesynthetase in vitro led to an increase in the rate of selenophosphate formation, indicating that under the action of NifS selenium derived from L-selenocysteine is a better substrate than selenide for selenophosphatesynthetase. That is, for $E$. coli, the selenium donor necessary for the conversion of serine to selenocysteine -tRNASec was selenophosphate. Selenophosphate is a rich energy source, where the selenium trace element is directly linked to the phosphorus atom (Glass et al., 1993).

The research revealed that $E$. coli can produce specific protein types (AdhP, Idh, OmpC and AceA) which are related to the synthesis of SeNPs and responsible for generating homogeneous SeNPs (Dobias et al., 2011). In addition, these numerous groups of microorganisms can reduce the toxic soluble forms of $\mathrm{Se}$ (VI)/Se (IV) to less toxic insoluble $\mathrm{SeO}$ visible as red nanoparticles - SeNPs. It turned out that SeNPs obtained using microorganisms have a negative zeta potential which causes a small tendency towards agglomeration, i.e. SeNPs exhibited greater resistance to maintaining the degree of dispersion (Shirsat et al., 2015).

Among the bacteria which can reduce Se (IV), the distribution of alpha-, beta-, gamma-, delta-proteobacteria and Firmicutes was performed (Shirsat et al., 2015; Tan et al., 2016; Lampis et al., 2017). Selenium metabolism occurs with selenophosphate synthetase (Veres et al., 1994), and selenocysteine synthase (SecS) (Cone et al., 1976; Forchhammer \& Böck, 1991). Selenophosphate synthetase generates a selenium donor for the SeCys biosynthesis by eubacteria. The enzymes of SecS are involved in biosynthetic pathways of eukaryotes and archaea, where an additional step is present in comparison with eubacteria, where seryl-tRNA(Ser)Secphosphodies phosphorilizes into phosphoseryl-tRNA(Ser)Sec by means of phosphoseryl-tRNA(Ser)Seckinase, with the formation of selenocysteyltRNA(Ser)Sec which is catalyzed by selenocysteine synthase (SecS)
(Yuan et al., 2006). Se-Cys can be metabolized by the pyridoxal phosphate-dependent selenocysteinelyase proteins for release of elemental selenium (Lacourciere \& Stadtman, 1998).

Thus, SeNPs are formed not only in aerobic and anaerobic conditions, but also appear in the cytoplasm, periplasm or outside cells of different bacteria (Nancharaiah \& Lens, 2015), including different mechanisms of Se (IV) - reduction. Generated by microorganisms, $\mathrm{Se}^{0}$ or SeNPs can be released by cells, by lysis of cells, or by vesicles (Kessi \& Hanselmann, 1999). In the biological aspect, bacteria of the species $B$. subtilis are a subject of interest because of the fact that when aerobically grown, in the presence of selenite, they can form spherical SeNPs (Glass et al., 1993; Etezad et al., 2009). Various hypotheses were proposed to describe the mechanism of microbial synthesis of SeNPs. This, first of all, is a twostage recovery process from $\mathrm{SeO}_{4}^{-2}$ to $\mathrm{SeO}_{3}^{-2}$ with the subsequent accumulation of insoluble elemental selenium $\mathrm{Se}^{0}$, with the help of catalysts selenium and selenium reductases (Wadhwani et al., 2016).

Thus, gram-positive bacteria and gram-negative microorganisms may have different mechanisms of selenite-reducing capacity (Newton \& Fahey, 1989; Kessi \& Hanselmann, 2004).

However, a prerequisite for high tolerance to selenite may be the high cytoplasmic level of disulfide-bearing molecules that function as catalysts for the recovery of disulfides and a functional system of protection against oxidative stress. Oxidation of a number of organic substrates (eg. acetate, lactate, pyruvate, glyceroland ethanol) or hydrogen may be associated with the reduction of arsenate and selenate, but the actual donor used is different from species to species. The microbial reduction of $\mathrm{SeO}_{4}^{-2}$ is known to take place in a wide range of microorganisms. Bacterial synthesis of SeNPs is often achieved by a reduction step where $\mathrm{SeO}_{3}^{-2}$ is an intermediate product. $B$. subtilis has been reported for the production of biogenic spherical shaped zero-valent SeNPs with diameters ranging from 50 to $400 \mathrm{~nm}$ (Wang et al., 2010). Periplasmic SER (selenate reductase) and membrane-bound arsenates of microorganisms contain molybdenum (Stolz \& Oremland, 1999).

The system of detoxification of selenium bacteria of the species B. subtilis does not depend on the acceptors of the electrons of nitrite or sulfate, but depends on the substrate. For $B$. subtilis, the accumulation of $\mathrm{Se}^{0}$ granules in the cell or between the cell wall and the plasma membrane is characteristic (Garbisu et al., 1996).

However, the presence of granules of selenium was observed temporarily during balanced growth of $B$. subtilis cells which were adapted to the selenite-containing medium; the presence of deposits for selenium was not obvious. For the formation of SeNPs deposits after adding $1 \mathrm{mM}$ solution of selenite to $B$. subtilis cultivation medium, creating a balanced growth of cells is not necessary. The appearance and formation of SeNPs can cause lysozyme treatment of $B$. subtilis (Garbisu et al., 1999). The lack of accumulation of SeNPs in the internal compartments of $B$. subtilis can contribute to the accumulation of selenenzymes. The property of cultures of $B$. subtilis to accumulate $\mathrm{Se}^{0}$ in the form of SeNPs in the internal cellular compartment, in the reductive dissimilation of selenite can be used not only for biological purification, but also for SeNPs products.

It should be noted that microbial reductions of selenium compounds occur both in the periplasmic space (intracellular) and extracellular space (Oremland et al., 2004) with the formation of biogenic elemental selenium nanoparticles BioSeNP that are stable and remain in the colloidal suspension for weeks (Eswayah et al., 2016).

Naturally, microorganisms can assimilate elemental selenium $\mathrm{Se}^{0}$ (Verma et al., 2008; Palomo-Siguero \& Madrid, 2017) and form selenium organic compounds Se-Cys, Se-Met (Calomme et al., 1995; Stolz \& Oremland, 2002; Stolz \& Oremland, 2006; Palomo-Siguero \& Madrid, 2017).

That is why it is necessary to reveal the effects of selenium nanoparticles on the biological properties of B. subtilis IMV B-7392, which is genetically related to $B$. subtilis 168 (Banerjee \& Hansen, 1988; Klein et al., 1992) for the development of the novel biological BioSeNP as food supplements, forage additives or plant nutritions.

Therefore, the objective of this work was characterizing the aqueous selenium citrate solution (Nano-Se) and its interaction with $B$. subtilis IMV B-7392 for development of probiotic nano-selenium-containing products. 


\section{Materials and methods}

Characterizations of Nano-Se was carried out using transmission electron microscopy (TEM) and UV-spectra were also obtained. The aqueous selenium citrate solution Nano-Se (TUU 15.8-35291116008:2009) was obtained by ablation of selenium granules and supplied by the LLC "Nanomaterials and Nanotechnologies" of Kyiv (Kosinov et al., 2008), in the concentration of $0.2 \mathrm{mg} / \mathrm{mL}$.

Bacterial strain and growth conditions. B. subtilis IMV B-7392 was deposited in the collection of cell cultures at the Zabolotny Institute of Microbiology and Virology. B. subtilis IMV B-7392 was grown on meatpeptone agar (MPA). Daily cultures of $B$. subtilis IMV B-7392 in the doses $\left(10^{2}-10^{8}\right.$ cells $\left./ \mathrm{mL}\right)$ were used in the work, using optical density standards. Culture $B$. subtilis IMV B-7392 was grown on meat-peptone agar (MPA) in presence and absence of Nano-Se $\left(0.2 \times 10^{-3} \mathrm{mg} / \mathrm{mL}\right)$ aerobically with agitation speed of $240 \mathrm{rpm}$ in the temperature of $30^{\circ} \mathrm{C}$ for 48 hours, followed by centrifuge at $6000 \mathrm{rpm}$ for $10 \mathrm{mins}$. For prolonged storage, lyophilization of biomass of $B$. subtilis culture was performed with control of bacterial purity of the preparations. The amount of viable cells obtained during the lyophilization of biomass in the presence and absence of Nano-Se $\left(0.2 \times 10^{-3} \mathrm{mg} / \mathrm{mL}\right)$ or $\mathrm{Na}_{2} \mathrm{SeO}_{3}(0.01 \mathrm{mg} / \mathrm{mL})$ with cryoprotectant was $(1.2 \pm 0.02) \times 10^{10}$ cells $/ \mathrm{mL}$.

TEMMeasurements of Nano-Se. TEM analyses were carried out to study size and shape of Nano-Se. The Nano-Se suspension $(0.02 \mathrm{mg} / \mathrm{mL})$ was applied on carbon-coated copper transmission electron microscope (TEM) grids and air-dried. The size of the particles was measured manually.

Preparation of B. subtilis for TEM. B. subtilis IMV B-7392 cells were grown by daily transfer in MPA incubated at $37^{\circ} \mathrm{C}$ and then were taken by using a sterile inoculating loop and put into the sterile $0.15 \mathrm{M} \mathrm{NaCl}$ solution. B. subtilis in the doses of $10^{9}$ cells $/ \mathrm{mL}$ were maintained in $0.15 \mathrm{M} \mathrm{NaCl}$ for 30 minutes, in the absence and presence of Nano-Se $0.2 \times 10^{-3} \mathrm{mg} / \mathrm{mL}$ each sample was applied to the grids and dried.

TEM analyses were performed to confirm Nano-Se uptake by B. subtilis IMV B-7392 and visualization of the Nano-Se effects on morphology of B. subtilis IMV B-7392 cells with the use of a JEM-1400 electron microscope (Japan).

UV-VIS measurements of Nano-Se were performed with Specord spectrophotometer using $l \mathrm{~cm}$ cuvettes. All absorbance measurements were performed in $20-25^{\circ} \mathrm{C}$.

Determination of the property of Nano-Se to enhance the production of metabolites was carried out in $0.15 \mathrm{M} \mathrm{NaCl}$ by exposure to $B$. subtilis daily cultures $\left(10^{2}\right.$ cells $\left./ \mathrm{mL}\right)$ in the presence and absence of Nano-Se $0.2 \times$ $10^{-3} \mathrm{mg} / \mathrm{mL}$ ( $37^{\circ} \mathrm{C}$ for 24 hours). The obtained Nano-Se and the supernatants' protein content of exometabolites of $B$. subtilis were observed by measuring the UV - visible spectrum with Specord spectrophotometer using a quartz cuvette (length of $1 \mathrm{~cm}$ ).

In the supernatants the protein content of exometabolites was determined by measuring the UV - Visible spectrum at $\lambda=235$ and $280 \mathrm{~nm}$ using the formula:

$$
\mathrm{C}=\left(\mathrm{A}_{235}-\mathrm{A}_{280}\right): 2.51 \text {, }
$$

where, the $\mathrm{C}$ is protein concentration $(\mathrm{mg} / \mathrm{mL}), \mathrm{A}$ is the absorption maximum at $\lambda_{1}$ and $\lambda_{2}, 2.51-$ coefficient expressing the average ratio of the extinction coefficient (E) at $\lambda_{235}$ and $\lambda_{280} \mathrm{~nm}$.

The spectrophotometric assay allowed us to determine the amount of protein-containing substances by absorption in the ultraviolet region of the spectrum in the samples.

The results of the experiments were statistically processed taking into account Student's coefficients for $n=5$. The calculations were performed using OriginLab Pro 8 software (Glanz, 1998). Differences with $\mathrm{P}<0.05$ were considered statistically significant.

\section{Results}

Characterizations of Nano-Se. TEM analysis of the selenium nanocarboxylates indicated the presence of Nano-Se (Fig. 1). The TEM image of Nano-Se shows monodiperse spherical shape and size of $4-8 \mathrm{~nm}$.

The Nano-Se was characterized by UV-Vis spectroscopy. Using the spectrophotometric method, the spectrophotometry of nanoparticles of selenium was carried out. The study was performed on the basis of infor- mation on selenium, Se, atomic number 34, group 16. According to (Oudhia, 2012), the Nano-Se can be measured by using UV-Vis spectroscopy and calculation of the extinction coefficient according to the BeerLambert law $\mathrm{A}=\varepsilon \times \mathrm{c} \times \mathrm{L}$, where $\mathrm{A}$ is the optical density, $\varepsilon-$ molar absorptivity for the dissolved substance at the specified wavelength $(\lambda), \mathrm{c}-$ molar concentration, $\mathrm{L}$ - light path length in centimeters.

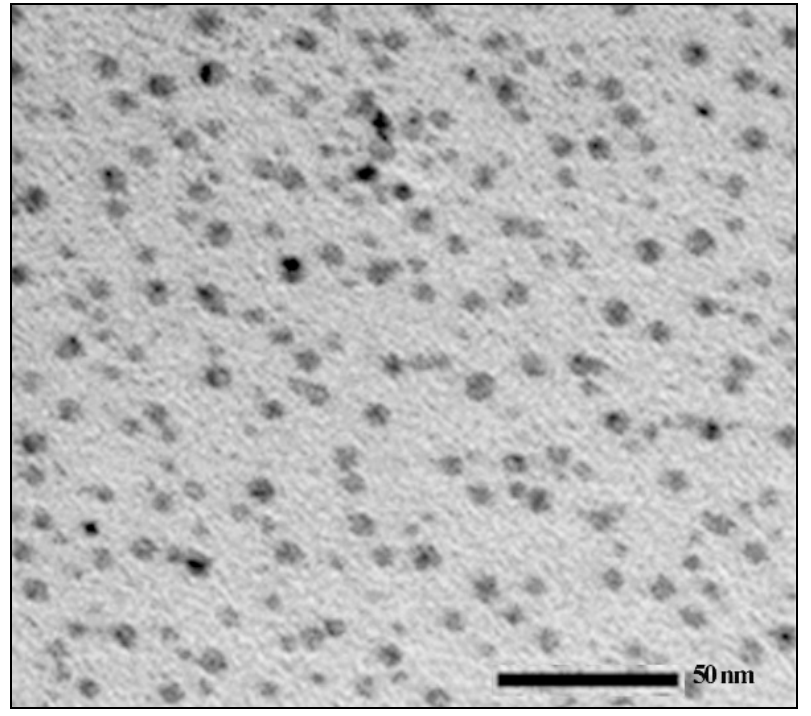

Fig. 1. TEM image of Nano-Se nanoparticles revealed size of particles $4-8 \mathrm{~nm}$

UV-Visible Spectrum colloidal solution Nano-Se exhibited absorption maxima at $210 \mathrm{~nm}$ (Fig. 2). The absorption peak at the value of $210 \mathrm{~nm}$ was in the ultra-violet region $\left(\lambda_{\max }=210 \mathrm{~nm}\right)$. UV-VIS spectra of Nano-Se were obtained due to the properties of the 16 groups of elements of the Mendeleev table (Oudhia, 2012). Based on the received UV-VIS spectra, we can state that nanoparticles are not aggregated, and according to the Gaussian distribution have a spherical shape (Carotenuto et al., 2000; Selim et al., 2015). The absorbance of the colloidal solution NanoSe was measured after different time intervals for confirming the stability of the solution.

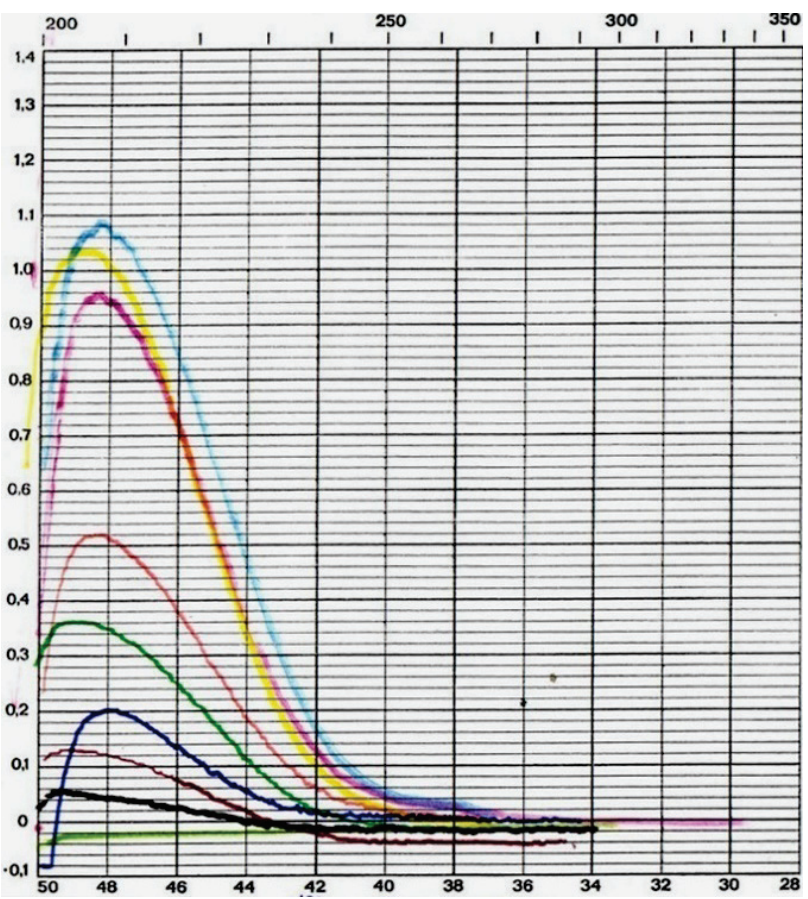

Fig. 2. UV-VIS spectra of Nano-Se nanoparticle dilution: $-1: 10 ;-1: 15 ;-1: 20 ;-1: 25 ;-1: 35$; $-1: 40 ;-1: 100 ; \quad 1: 200 ;-1: 250$ 
Determinations of the property of Nano-Se to enhance the production of metabolites show that the exposure of $B$. subtilis to Nano-Se, in $0.15 \mathrm{M}$ $\mathrm{NaCl}$, in the UV-Vis region of the Spectra, was accompanyied by a significant increase in the accumulation of purified protein-containing exometabolites (Fig. 3)

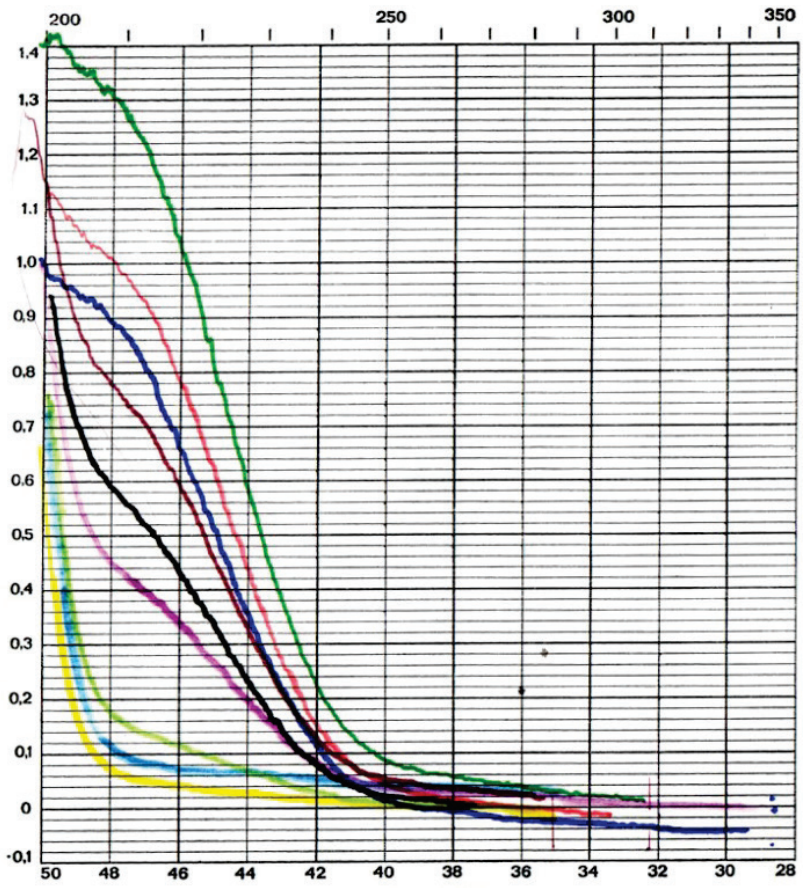

Fig. 3. Determination of accumulation of protein exometabolites by $B$. subtilis IMVB-7392 $\left(10^{2}\right.$ cells $\left./ \mathrm{mL}\right)$ in $0.15 \mathrm{M} \mathrm{NaCl}$, in the absence and presence of Nano-Se, dilution $-1: 4$ (control);

$$
-1: 40 ;-1: 100 ;-1: 200 ; \_1: 10 ;-1: 25 \text {; }
$$$$
-1: 20 ;-1: 30
$$

For control samples, we determined that exposure of $B$. subtilis in the absence of Nano-Se was accompanied by accumulation of exometabolite proteins, the corresponding dilutions were $1: 4$, therefore the concentrations were $0.144 \pm 0.01 \mathrm{mg} / \mathrm{mL}$. Simultaneous study of the samples of probiotic culture $B$. subtilis, in the presence of Nano-Se, taking into account the dilution $(1: 10)$, was accompanied by the accumulation of the content of the metabolite proteins to $2.63 \pm 0.02 \mathrm{mg} / \mathrm{mL}(\mathrm{P}<0.05)$.

That is, under the effect of Nano-Se, accumulation of protein-containing substances by culture $B$. subtilis IMV B-7392 increased by 18.2 times. Thus, according to spectral characteristics, we determined effective concentrations of Nano-Se for increase in the production of biologically active substances by B. subtilis IMV B-7392. Previously, we conducted work on the evaluation of effective concentrations of Nano-Se to modu- late the enzymatic activity of phagocytic cells. The system of phagocytes showed the property of nano-selenium to activate the metabolic activity of phagocytes in optimal doses of Nano-Se $2 \times 10^{-5} \mathrm{mg} / \mathrm{mL}$ (Tymoshok et al., 2017). Earlier, the determined optimal doses of Nano-Se for the activation of phagocytes were used to study the interaction of Nano-Se with probiotic culture of $B$. subtilis IMB B-7392. TEM analyses were performed to visualize the effect of Nano-Se on the morphology of B. subtilis IMV B-7392 cells to produce selenium-enriched probiotics.

Typical transmission electron micrographs for B. subtilis IMV B7392, without exposure to nanoparticles, are shown in Figure 4. We found that $B$. subtilis IMV B-7392 cells had the shape of a rod, and due to the hard protective endospore, the electrons penetrated poorly, which indicates the normal, physiological condition of the cells (Fig. 4).

At the same time, the introduction of Nano-Se in the final concentration of $0.2 \times 10^{-3} \mathrm{mg} / \mathrm{mL}$ to $B$. subtilis IMV B-7392 during exposures of 20 minutes was accompanied by change in the cell morphology.

Morphological changes of $B$. subtilis after Nano-Se treatment. It was shown that Nano-Se first interacted with the outer membrane of the B. subtilis, after that the nanoparticles entered the cells (Fig. 4).

Thus, the treatment of $B$. subtilis IMV B-7392 with Nano-Se in the final concentration of $0.2 \times 10^{-3} \mathrm{mg} / \mathrm{mL}$, over 20 minutes exposition, was accompanied by change in the cell morphology. The addition of Nano-Se in the final concentration of $0.2 \times 10^{-3} \mathrm{mg} / \mathrm{mL}$ to B. subtilis IMV B-7392 and 20-minute exposure was accompanied by change in cell morphology, adsorption of Nano-Se and uptake of Nano-Se by bacterial culture.

Electron micrographs (JEM-1400) of the morphological interaction between Nano-Se and B. subtilis IMV B-7392 (Fig. 5c, d, e) indicate Nano-Se $0.2 \times 10^{-3} \mathrm{mg} / \mathrm{mL}$ absorption on cellular surface structures (Fig. $5 \mathrm{a}, \mathrm{b}$, $\mathrm{f}, \mathrm{g}, \mathrm{h}, \mathrm{i}, \mathrm{j}, \mathrm{k}$ ) indicate internal spherical structure of Nano-Se in B. subtilis IMV B-7392 cells. Some electron-dense granules appeared in the cytoplasm of B. subtilis IMV B-7392 after 30-min Nano-Se treatment. After exposure to Nano-Se $0.2 \times 10^{-3} \mathrm{mg} / \mathrm{mL}$ the bacterial cells still maintained their integrity.

The effect of Nano-Se on the culture of B. subtilis IMV B-7392 was accompanied by changes in the size of bacteria, the formation of a binucleate cell with divided nucleoid (Fig. 4c, d). The interaction between Nano-Se and B. subtilis IMV B-7392 led to a temporary increase in porosity in the membrane, which was accompanied by the formation of bubbles (Fig. 5l). Electron microscopic (JEM-1400) image of B. subtilis IMV B7392 showed the interaction of Nano-Se with the cell surface and the presence of spherical Nano-Se in the internal cellular compartments during application of Nano-Se in the final concentration of $0.2 \times 10^{-3} \mathrm{mg} / \mathrm{mL}$. It has been established that the binding of Nano-Se to cell surface structures is accompanied by changes in the size of bacteria (Fig. 4c, d). We observed elongation of cells $B$. subtilis IMV B-7392 to $>5 \mu \mathrm{m}$, accompanied by the binding of Nano-Se to cell surface structures.

Interaction of $B$. subtilis IMB B-7392 with SeNPs in the concentration $0.2 \times 10^{-3} \mathrm{mg} / \mathrm{mL}$ was not been associated with change in the growth the bacterial culture.

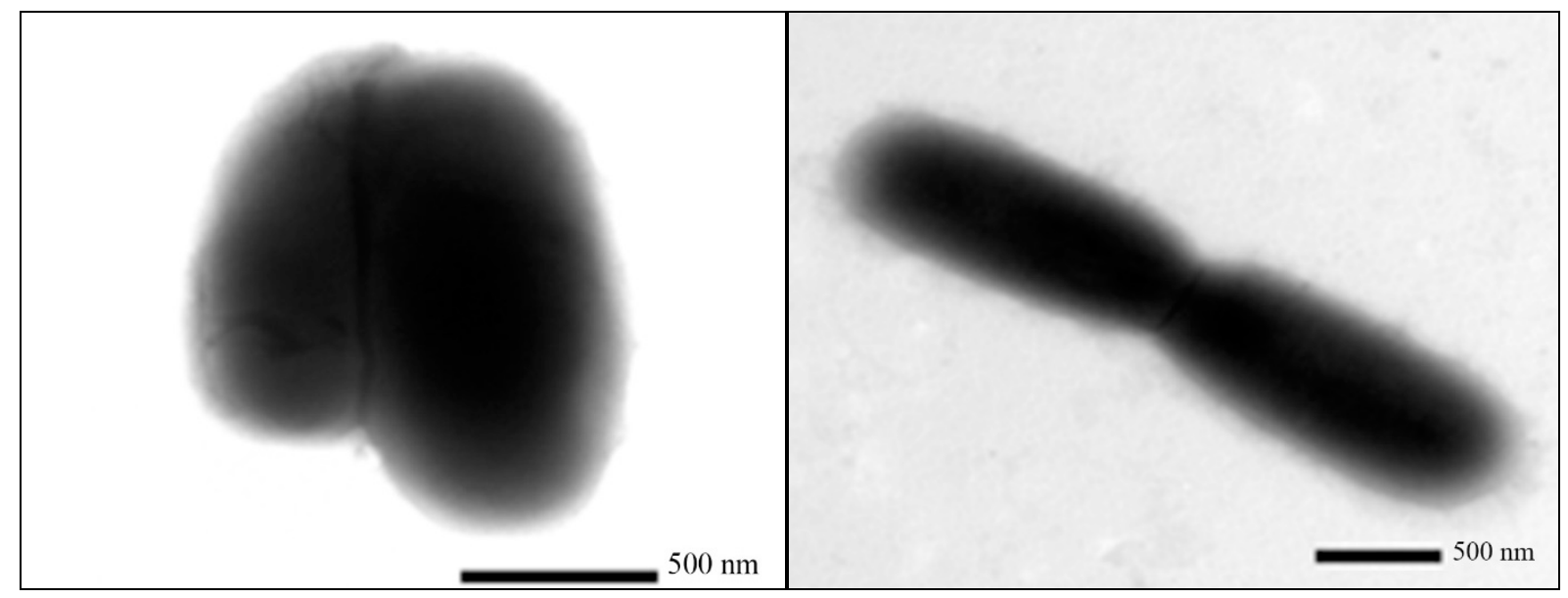

Fig. 4. TEM image of B. subtilis IMB B-7392 (control of cells) 


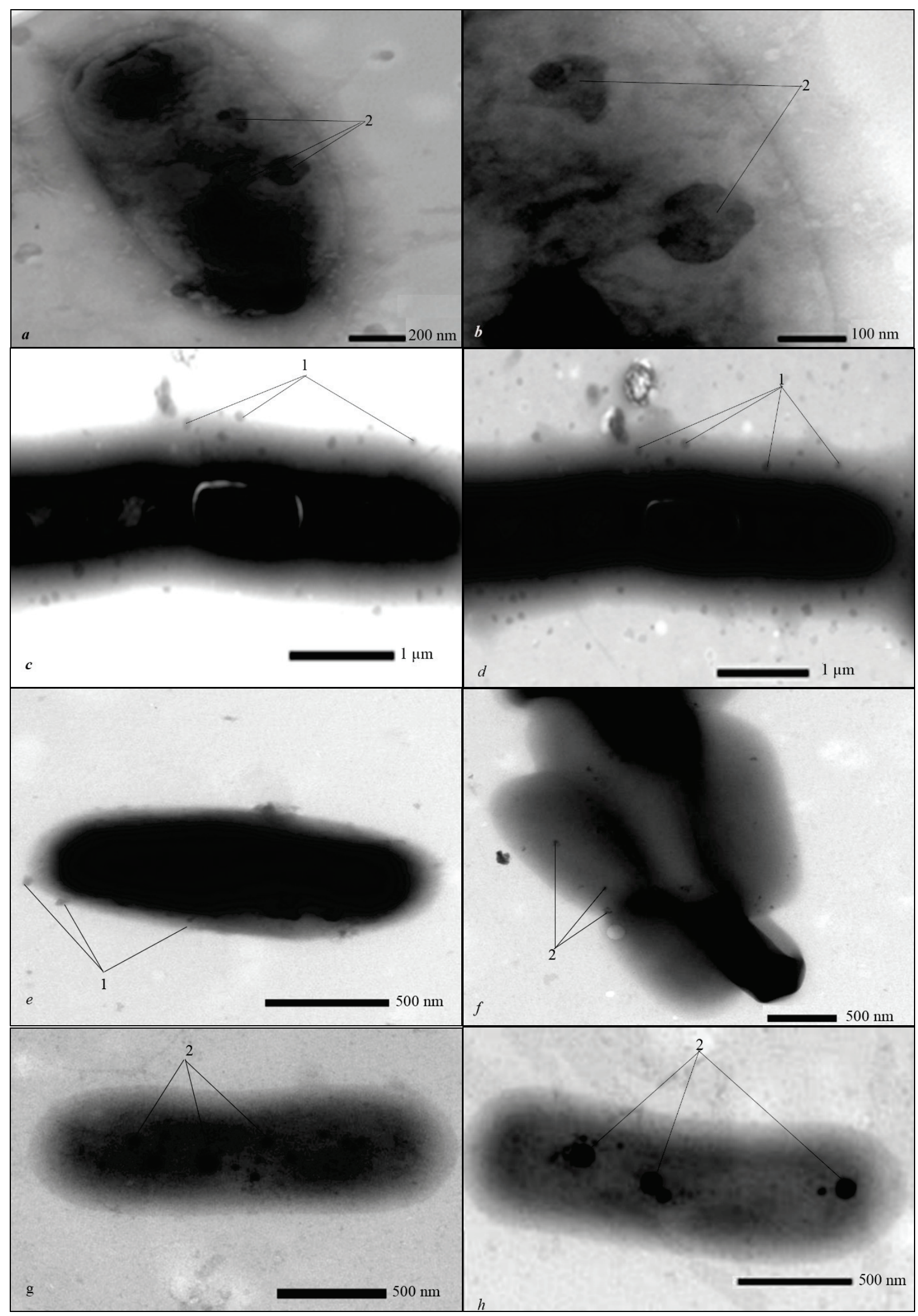

Fig. 5. Transmission electron micrographs (JEM-1400) of the morphological interaction between Nano-Se and B. subtilis IMV B-7392: 1 -adsorption of Nano-Se nanoparticles; 2 - internalization of Nano-Se nanoparticles; 3 - formation of bubbles after damage to outer membrane of $B$. subtilis IMV B-7392 caused by Nano-Se 


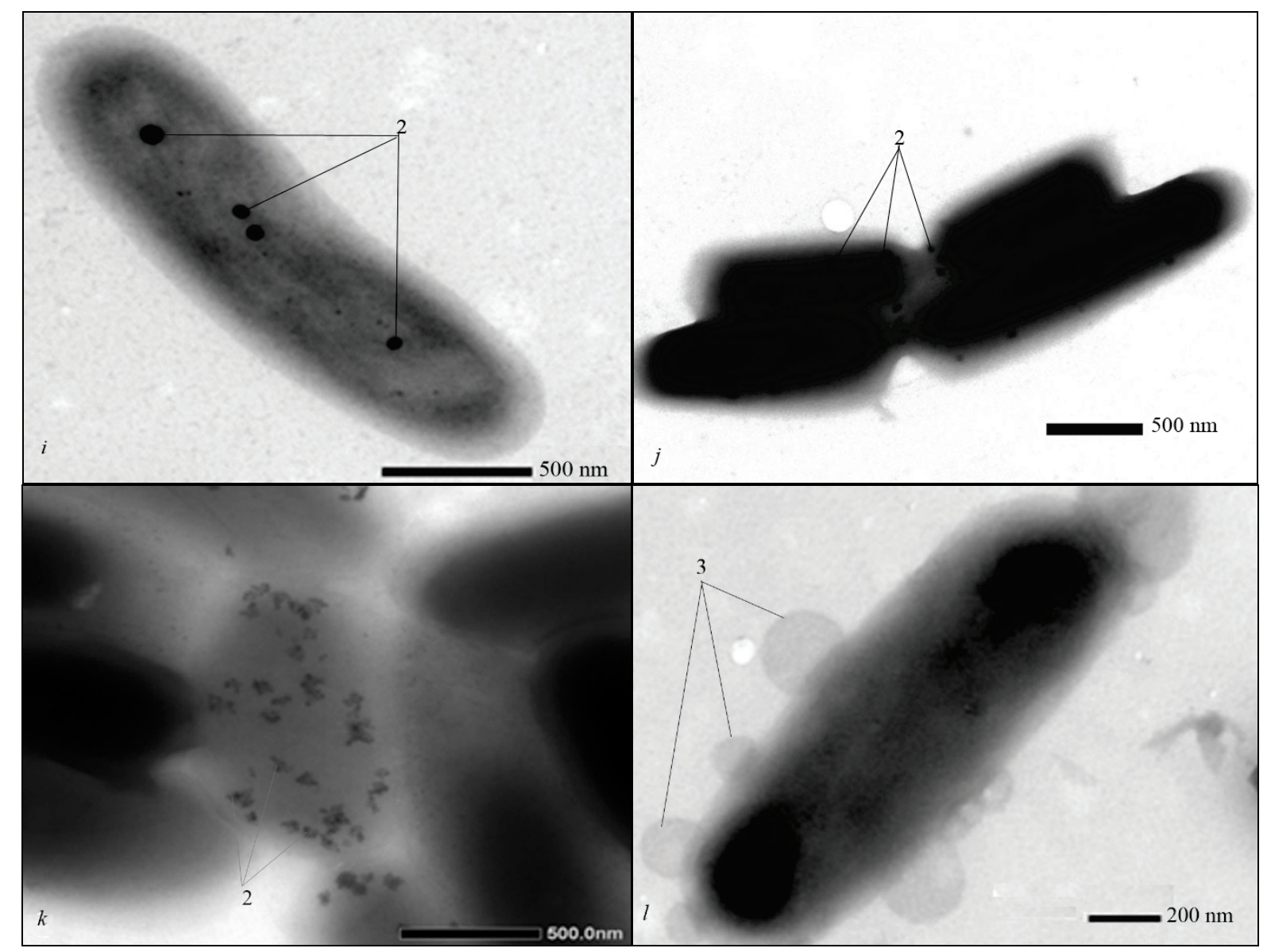

Fig. 5. Transmission electron micrographs (JEM-1400) of the morphological interaction between Nano-Se and B. subtilis IMV B-7392: see Fig. 5

In particular, for the first time, we have described that the combinations of using Nano-Se and B. subtilis IMB B-7392 are accompanied by a significant increase in the output of biologically active substances (exometabolites). Nano-Se in the concentrations of $0.2 \times 10^{-3} \mathrm{mg} / \mathrm{mL}$ contributed to the loss of integrity of $B$. subtilis IMV B-7392, accompanied by higher cell permeability of cells and increase in the output of intracellular metabolites.

\section{Discussion}

The present study was designed to characterize the interaction of B. subtilis IMB B-7392 and Nano-Se for developing probiotic nano-selenium containing products. Transmission electron microscopy and spectroscopy analyses demonstrate that Nano-Se obtained by the method of selenium ablation have size ranging $4-8 \mathrm{~nm}$. UV-Vis analysis of Nano-Se revealed that nanoparticles did not aggregate, and according to the Gaussian distribution, they had a spherical shape showing peak at $210 \mathrm{~nm}\left(\lambda_{\max }=\right.$ $210 \mathrm{~nm}$ ). The characteristics of these curves provide information about quantity of nanoparticles (Overschelde et al., 2013).

The similar UV-Vis absorption spectra were obtained by Cui et al. (2018) by green synthesis of selenium nanoparticles from hawthorn fruit extract (HE) and provided information on their UV-visible spectroscopy. Cui et al. (2018) considered HE-selenium nanoparticles as a candidate for further evaluation as a chemotherapeutic agent for human liver cancer.

Furthermore, Bacillus cereus produced selenium nanoparticles during selenite/selenate reduction through membrane-associated reductase(s) with formation of nanoparticles which had the intensity of UV-visible absorption at $420-450 \mathrm{~nm}$ (Pouri et al., 2017).

Research has shown that exposure to B. subtilis IMV B-7392 in the presence of Nano-Se was accompanied by the rapid uptake of Nano-Se by bacterial culture. Representative transmission electron micrographs have shown the amounts of the electron-dense granules inside the cells of B. subtilis IMV B-7392. Similar results have been obtained by Kumar et al. (2011a). Their data demonstrate significant internalization of zinc oxide $(\mathrm{ZnO})$ and titanium (IV) oxide $\left(\mathrm{TiO}_{2}\right)$ nanoparticles $(\mathrm{NPs})$ in Esche- richia coli in a dose-dependent manner. Internalization of $\mathrm{ZnO} \mathrm{NP}$ to E. coli was observed rapidly after 60-min $\mathrm{ZnO} \mathrm{NP}$ treatment and exhibited an increase indicating granularity. They have demonstrated that smaller NPs can enter the bacterial cells and can interact with the cellular macromolecules (Kumar et al., 2011a) but the mechanism through which the NPs could pass through the bacterial cell wall and membranes is still unknown.

Increase in the granularity of $S$. typhimurium TA98 cells treated with $\mathrm{ZnO} N P$ s or $\mathrm{TiO}_{2}$ NPs was shown by Kumar et al. (2011b). They demonstrated the uptake of $\mathrm{ZnO} N \mathrm{NP}$ or $\mathrm{TiO}_{2} \mathrm{NPs}$ in S. typhimurium using flow cytometry. The TEM studies have proven the internalization of these NPs in S. typhimurium TA98 cells. Scanning electron microscopy coupled with energy dispersive X-ray spectroscopy (SEM-EDS) confirmed the protein coating over NPs (Kumar et al., 2011b).

A similar observation was made by Kloepfer et al. (2005), they have proven the property of $B$. subtilis to uptake nanosized CdSe and $\mathrm{CdSe} / \mathrm{ZnS}$ Quantum Dots (QD) conjugates in the bacteria through purinedependent mechanisms. The studies showed that incubation of $B$. subtilis cells with bare CdSe QD conjugates in the room light is accompanied by elongation of cells to $>10 \mu \mathrm{m}$ in many cases, reflecting decreased rates of cell division (Sargent, 1975; Kloepfer et al., 2005; Javed et al., 2015). For genetically related $B$. subtilis $168 / \mathrm{S}$, the length of the cells was found to be dependent on the growth rates, and is known for mononuclear, binucleate, and Cross-wall separation cells (Sargent, 1975; Burdett et al., 1986). However, under the influence of Nano-Se, a change in the size of $B$. subtilis IMV B-7392 occurred. Figure 4c, d shows a binucleate cell with divided nucleoid; this cell corresponds to stage 3 - binucleate cells (Burdett et al., 1986). Elongation of $B$. subtilis cells under the effect of very low concentrations of $\mathrm{Cd}$ led to the inhibition of DNA repair enzymes, which can inhibit cell division (Hartwig et al., 2002). Research on the interaction of nanoparticles and bacterial cells revealed that NPs can interact with the bacterial membrane due to electrostatic interactions (Thill et al., 2006). The interaction of NPs and bacterial cells can lead to loss of membrane integrity. Thus, similarly to interaction of NPs of titanium oxide and 
E. coli (Sohm et al., 2015), the interaction between B. subtilis IMV B7392 and Nano-Se was accompanied by an increase in the permeability of the membrane (Fig. 5l), but at this stage the effects are reversible, since the cell viability is maintained. According to spectrometry, an increase in the output of biologically active substances is observed (Fig. 2b). Therefore, the incubation of $B$. subtilis IMV B-7392 with Nano-Se for 30 minutes changes the surface of bacterial cells. Cells are well visible by TEM. In addition, similarly to $B$. subtilis interactions with TzPdNPs (Joardar et al., 2016), bubble formation were observed on the cell surface (Fig. 5l).

Therefore, the penetration of positively charged NPs into negatively charged bacterial cells is crucial for the activity of NPs as bactericidal materials. However, the penetration of positively charged NPs into B. subtilis cells is likely to disrupt the integrity of the membrane, which leads to the formation of bubbles. Similar results were obtained (Selim et al., 2015), showing that direct contact between titanium oxide and a bacterial cell increases the permeability of the membrane, but at this stage, the effects are reversible. We obtained similar data and the penetration of Nano-Se into $B$. subtilis IMV B-7392 cells in the concentration of $0.2 \times 10^{-3} \mathrm{mg} / \mathrm{mL}$ was not accompanied by the manifestation of bactericidal or bacteriostatic effects of Nano-Se on this culture.

However, it should be noted that while interacting with Nano-Se in the concentration $\left(0.2 \times 10^{-3} \mathrm{mg} / \mathrm{mL}\right)$, the growth of bacteria $B$. subtilis IMB B-7392 did not change. According to TEM, aerobic cultivation B. subtilis IMV B-7392 for 48 hours in the presence and absence of NanoSe $\left(0.2 \times 10^{-3} \mathrm{mg} / \mathrm{mL}\right)$ was not accompanied with the morphological difference between the bacteria.

We have shown that Nano-Se were absorbed by $B$. subtilis IMV B7392 and/or attached to their cellular structures rapidly within 30 minutes. Similar results were obtained by the authors (Javed et al., 2015) when cultivating B. subtilis at $\mathrm{pH} 7$ and $37^{\circ} \mathrm{C}$ with selenite, so over 30 minutes $23-25 \%$ reduction of selenite that was introduced into the culture medium occurred.

For B. subtilis, a characteristic feature is the presence of an induced system of selenite detoxification, and not the transfer of dissimilation electrons (Garbisu et al., 1995). It is known that glucose and sucrose can intensify the metabolism of $\mathrm{Na}_{2} \mathrm{SeO}_{3}$ in the case of the enrichment of nutrient medium with $\mathrm{Na}_{2} \mathrm{SeO}_{3}$ in the concentration of $1 \mathrm{mM}$. The range of concentrations of $\mathrm{Na}_{2} \mathrm{SeO}_{3}$ suitable for the growth of $B$. subtilis is from $0.6 \mu \mathrm{M}$ to $5 \mathrm{mM}$ (from 50 to $395 \mathrm{ppm}$ selenium). In the presence of $0.6 \mu \mathrm{M}$ selenite, B. subtilis removed $95 \%$ of $\mathrm{Na}_{2} \mathrm{SeO}_{3}$ from the nutrient medium (Paige et al., 2015).

So, the most optimal concentration of sodium $\mathrm{Na}_{2} \mathrm{SeO}_{3}$ for metabolism of culture B. subtilis IMB B-7392 was the concentration $(0.01 \mathrm{mg} / \mathrm{mL})$. Addition of high concentrations of $\mathrm{Na}_{2} \mathrm{SeO}_{3}$ to the incubation medium led to decrease in the growth of biomass of B. subtilis cells IMV B-7392. The property of $B$. subtilis to accumulate biomass in enrichment of the culture media $\left(0.2 \times 10^{-3} \mathrm{mg} / \mathrm{mL}\right)$ with Nano-Se is due to the properties of the $B$. subtilis bacterium species towards $\mathrm{Na}_{2} \mathrm{SeO}_{3}$ metabolism (Dhevahi \& Gurusamy, 2014) and biotransformation of $\mathrm{Na}_{2} \mathrm{SeO}_{3}$ to Nano-Se (Wang et al., 2010; Paige et al., 2015; Chandramohan et al., 2018).

The presence of selenite in the culture medium of $B$. subtilis causes structural changes in cells, increase in the content of thioredoxin and the NADP-thioredoxine reductase enzyme associated with it (Garbisu et al., 1999; Nelersa et al., 2011). Selenites can contribute to the oxidation of thiols to sulfenic acid. Reverse transition thiol $\leftrightarrow$ disulfide - is a fairly common biochemical redox process, during which a relatively stable disulfide bond forms. The property of selenite to influence the biochemical response of $B$. subtilis and the ditiol system determines its activity as a modulator of thioredox-dependent systems that are responsible for supporting redox cell potentials.

The property of B. subtilis IMV B-7392 to uptake Nano-Se may be interesting considering the property of $B$. subtilis to reduce selenite in vitro by involving the thioredoxin system consisting of NADPH, thioredoxin reductase. Thioredoxin can reduce protein disulfides through redox-active dithiols. In B. subtilis, thioredoxin is induced in the presence of selenite (Garbisu et al., 1999; Nelersa et al., 2011). B. subtilis is a subgroup of microorganisms which has the property to metabolise selenium. The mechanism of selenite reduction in these bacteria may be similar to the one proposed for the proteobacteria. The reduction of disulfides can be catalyzed by selenols, which may be present in bacterial cells as secondary products of the selenium metabolism (Singh \& Whitesides, 1991; Kessi \& Hanselmann, 2004).

Selenite in $B$. subtilis can be reduced by bacillithiol (Kessi \& Hanselmann, 2004), producing reduced organo-Se molecules (RS-Se-SR) and the highly reactive superoxide radical anion $\left(\mathrm{O}_{2}{ }^{\circ}\right)$. Thioredoxin can consume $\mathrm{O}_{2}{ }^{-}$and contributes to the conversion of $\mathrm{R}_{1} \mathrm{~S}-\mathrm{Se}-\mathrm{SR}_{2}$ to elemental $\mathrm{Se}^{0}$ (Kessi \& Hanselmann, 2004). The redox status of bacillithiol can be maintained by the thioredoxin/thioredoxin reductase system (Newton et al., 2009).

Thus, B. subtilis and some Lactobacillus species are considered as new selenium-metabolizing probiotics, which could convert selenium to selenoprotein (Sels) via selenide. Probiotic microorganisms can naturally synthesize selenium nanoparticles and assimilate exogenous nanoparticles. For Lactobacillus bacteria, the property to metabolize inorganic ions of selenium (IV) into Se-methyloselenocysteine, Se-methionine and other unidentified forms was observed (Kurek et al., 2016).

The importance of developing new selenium-containing probiotics is due to the following facts: they can provide conversion of inorganic selenium into its organic forms (Jin et al., 2018). Se enters the food chain through plants and selenium-enriched yeasts and probiotics. Selenium can be present in the form of sodium selenate, L-selenomethionine, sodium selenite and selenious acid, as well as in the form of selenium-enriched microorganisms (Rayman, 2004).

Selenium performs protective functions in the body. Selenides provide active participation in redox and antioxidant processes, cell respiration, and synthesis of specific functional enzymes (Garbisu et al., 1999; Kessi \& Hanselmann, 2004).

The antioxidant action of glutathione peroxidase family enzymes provides selective properties for the cardiovascular system. Deficiency of this element enhances the production of reactive oxygen types, synthesis of thromboxanes, increases platelet aggregation, and inhibits the reproducetion of the prostacyclin-protective factor of endothelium. Selenium activates the cellular, humoral level of immunity, promotes nonspecific resistance of the body. Selenium deficiency in the body leads to a decrease in the functional activity of neutrophils and their number has a negative effect on the formation of antibodies, inhibits the activity of natural killer cells (Zee et al., 2016). The fact of penetration into the internal compartments of the bacterial cells of NPs has attracted the attention of specialists, since it opens up the possibility of development of new antimicrobial drugs on their basis in spite of the growing threat of antibiotic resistance.

However, the factors of interaction of NPs and bacteria, as well as the mechanisms of their antibacterial action are completely unclear (Paige et al., 2015). We have established the optimal concentration of Nano-Se $\left(0.2 \times 10^{-3} \mathrm{mg} / \mathrm{mL}\right)$ for increasing the output of biologically active substances of $B$. subtilis IMV B-7392. The property of $B$. subtilis IMV B-7392 to bioaccumulate sodium selenite and Nano-Se in optimal doses was revealed.

Using TEM, we determined that exposure to B. subtilis IMV B-7392 in the presence of Nano-Se is accompanied by the rapid uptake of NanoSe by the bacterial culture during $30 \mathrm{~min}$. Penetration of Nano-Se in the internal compartments is accompanied by local deformation and transient porosity in the membrane of $B$. subtilis IMV B-7392 without rupturing it.

Penetration of Nano-Se in B. subtilis IMV B-7392 is accompanied with a significant increase in the accumulation of protein exometabolites. It was important because Bacillus species are considered as primary producers of bioactive secondary metabolites ( 800 compounds), while lactobacilli produce a much smaller amount of secreted compounds compared to Bacillus species (Bérdy, 2005).

The property of Nano-Se to cross the cell wall determines their prospect for use as antimicrobial agents and combining them with antibiotics, including beta-lactam antibiotics and aminoglycosides. Prospects of combining Nano-Se and beta-lactam antibiotics are due to the property of betalactams to suppress the synthesis of bacterial cell walls, and their features, namely the hydrophilic structure, which complicates penetration into the cells (Li \& Nikaido, 2004). The results indicate that $B$. subtilis IMV B7392 could potentially be used as carriers for Nano-Se.

The property of $B$. subtilis to uptake Nano-Se determines the potential benefits of $B$. subtilis for methods of transport agents, as well as enhancing 
the output of biologically active substances and developing probiotic nanoselenium containing products.

\section{Conclusions}

The interaction of $B$. subtilis IMV B-7392 with Nano-Se leads to the rapid uptake of Nano-Se by the bacterial culture and transient porosity in the membrane without rupturing it. The optimal concentration of SeNPs for increasing the output of biological activity of $B$. subtilis has been revealed. The property of Nano-Se to cross the cell wall of $B$. subtilis IMV B-7392 is crucial for determining ways of action and development of new-generation therapeutics.

\section{References}

Ayala-Castro, C., Saini, A., \& Outten, F. W. (2008). Fe-S cluster assembly pathways in bacteria. Microbiology and Molecular Biology Reviews, 72(1), 110-125.

Banerjee, S., \& Hansen, J. N. (1988). Structure and expression of a gene encoding the precursor of subtilin, a small protein antibiotic. Journal of Biological Chemistry, 263(19), 9508-9514.

Bérdy, J. (2005). Bioactive microbial metabolites. The Journal of Antibiotics (Tokyo), 58(1), 1-26.

Bityutskyy, V. S., Tsekhmistrenko, O. S., Tsekhmistrenko, S. I., Spyvack, M. Y., \& Shadura, U. M. (2017). Perspectives of cerium nanoparticles use in agriculture. The Animal Biology, 19(3), 9-17.

Böck, A. (2001). Selenium metabolism in bacteria. In: Selenium. Springer, Boston. Pp. 7-22.

Böck, A., Forchhammer, K., Heider, J., Leinfelder, W., Sawers, G., Veprek, B., \& Zinoni, F. (1991). Selenocysteine: The 21st amino acid. Molecular Microbiology, 5(3), 515-520.

Burdett, I. D., Kirkwood, T. B., \& Whalley, J. B. (1986). Growth kinetics of individual Bacillus subtilis cells and correlation with nucleoid extension. Journal of Bacteriology, 167(1), 219-230.

Burk, R. F. (1983). Biological activity of selenium. Annual Review of Nutrition, $3(1), 53-70$.

Calomme, M. R., Van den Branden, K., \& VandenBerghe, D. A. (1995). Selenium and Lactobacillus species. Journal of Applied Bacteriology, 79(3), 331-340.

Carotenuto, G., Pepe, G. P., \& Nicolais, L. (2000). Preparation and characterization of nano-sized Ag/PVP composites for optical applications. The European Physical Journal B - Condensed Matter and Complex Systems, 16(1), 11-17.

Chandramohan, S., Sundar, K., \& Muthukumaran, A. (2018). Monodispersed spherical shaped selenium nanoparticles (SeNPs) synthesized by Bacillus subtilis and its toxicity evaluation in zebrafish embryos. Materials Research Express, 5(2), 025020.

Cone, J. E., Del Rio, R. M., Davis, J. N., \& Stadtman, T. C. (1976). Chemical characterization of the selenoprotein component of clostridial glycine reductase: Identification of selenocysteine as the organoselenium moiety. Proceedings of the National Academy of Sciences, 73(8), 2659-2663.

Cui, D., Liang, T., Sun, L., Meng, L., Yang, C., Wang, L., Liang, T., \& Li, Q. (2018). Green synthesis of selenium nanoparticles with extract of hawthorn fruit induced HepG2 cells apoptosis. Pharmaceutical Biology, 56(1), 528-534.

Dhevahi, B., \& Gurusamy, R. (2014). Factors influencing production of lipase under metal supplementation by bacterial strain, Bacillus subtilis BDG-8. Journal of Environmental Biology, 35(6), 1151-1155.

Dobias, J., Suvorova, E. I., \& Bernier-Latmani, R. (2011). Role of proteins in controlling selenium nanoparticle size. Nanotechnology, 22(19), 195605.

Eswayah, A. S., Smith, T. J., \& Gardiner, P. H. (2016). Microbial transformations of selenium species of relevance to bioremediation. Applied Environmental Microbiology, 82(16), 4848-4859.

Etezad, S. M., Khajeh, K., Soudi, M., Ghazvini, P. T. M., \& Dabirmanesh, B. (2009). Evidence on the presence of two distinct enzymes responsible for the reduction of selenate and tellurite in Bacillus sp. STG-83. Enzyme and Microbial Technology, 45(1), 1-6.

Forchhammer, K., \& Böck, A. (1991). Selenocysteine synthase from Escherichia coli. Analysis of the reaction sequence. Journal of Biological Chemistry, 266(10), 6324-6328.

Forchhammer, K., Leinfelder, W., \& Böck, A. (1989). Identification of a novel translation factor necessary for the incorporation of selenocysteine into protein. Nature, 342(6248), 453-456.

Garbisu, C., Carlson, D., Adamkiewicz, M., Yee, B. C., Wong, J. H., Resto, E. Leighton, T., \& Buchanan, B. B. (1999). Morphological and biochemical responses of Bacillus subtilis to selenite stress. BioFactors, 10(4), 311-319.

Garbisu, C., Gonzalez, S., Yang, W. H., Yee, B. C., Carlson, D. L., Yee, A., Smith, N. R., Otero, R., Buchanan, B. B., \& Leighton, T. (1995). Physiological mechanisms regulating the conversion of selenite to elemental selenium by Bacillus subtilis. BioFactors, 5(1), 29-37.
Garbisu, C., Ishii, T., Leighton, T., \& Buchanan, B. B. (1996). Bacterial reduction of selenite to elemental selenium. Chemical Geology, 132, 199-204.

Glass, R. S., Singh, W. P., Jung, W., Veres, Z., Scholz, T. D., \& Stadtman, T. (1993). Monoselenophosphate: Synthesis, characterization, and identity with the prokaryotic biological selenium donor, compound SePX. Biochemistry, 32(47), 12555-12559.

Hartwig, A., Asmuss, M., Ehleben, I., Herzer, U., Kostelac, D., Pelzer, A., Schwerdtle, T., \& Bürkle, A. (2002). Interference by toxic metal ions with DNA repair processes and cell cycle control: Molecular mechanisms. Environmental Health Perspectives, 110(suppl. 5), 797-799.

Javed, S., Sarwar, A., Tassawar, M., \& Faisal, M. (2015). Conversion of selenite to elemental selenium by indigenous bacteria isolated from polluted areas. Chemical Speciation and Bioavailability, 27(4), 162-168.

Jin, W., Yoon, C., Johnston, T. V., Ku, S., \& Ji, G. E. (2018). Production of selenomethionine-enriched Bifidobacterium bifidum BGN4 via sodium selenite biocatalysis. Molecules, 23(11), 2860.

Joardar, S., Ray, S., Samanta, S., \& Bhattacharjee, P. (2016). Antibacterial activity of 3,6-di(pyridin-2-yl)-1,2,4,5-s-tetrazine capped $\mathrm{Pd}(0)$ nanoparticles against gram-positive Bacillus subtilis bacteria. Cogent Biology, 2(1), 1249232.

Kessi, J., \& Hanselmann, K. W. (2004). Similarities between the abiotic reduction of selenite with glutathione and the dissimilatory reaction mediated by Rhodospirillum rubrum and Escherichia coli. Journal of Biological Chemistry, 279(49), 50662-50669.

Kessi, J., Ramuz, M., Wehrli, E., Spycher, M., \& Bachofen, R. (1999). Reduction of selenite and detoxification of elemental selenium by the phototrophic bacterium Rhodospirillum rubrum. Applied Environmental Microbiology, 65(11), $4734-4740$.

Klein, C., Kaletta, C., Schnell, N., \& Entian, K. D. (1992). Analysis of genes involved in biosynthesis of the lantibioticsubtilin. Applied Environmental Microbiology, 58(1), 132-142.

Kloepfer, J. A., Mielke, R. E., \& Nadeau, J. L. (2005). Uptake of CdSe and $\mathrm{CdSe} / \mathrm{ZnS}$ quantum dots into bacteria via purine-dependent mechanisms. Applied Environmental Microbiology, 71(5), 2548-2557.

Kumar, A., Pandey, A. K., Singh, S. S., Shanker, R., \& Dhawan, A. (2011a). A flow cytometric method to assess nanoparticle uptake in bacteria. Cytometry A, 79(9), 707-712.

Kumar, A., Pandey, A. K., Singh, S. S., Shanker, R., \& Dhawan, A. (2011b). Cellular uptake and mutagenic potential of metal oxide nanoparticles in bacterial cells. Chemosphere, 83(8), 1124-1132.

Kurek, E., Ruszczyńska, A., Wojciechowski, M., Łuciuk, A., Michalska-Kacymirow, M., Motyl, I., \& Bulska, E. (2016). Bio-transformation of selenium in Se-enriched bacterial strains of Lactobacillus casei. Roczniki Panstwowego Zakladu Higieny, 67(3), 253-262.

Lacourciere, G. M., \& Stadtman, T. C. (1998). The NIFS protein can function as a selenide delivery protein in the biosynthesis of selenophosphate. Journal of Biological Chemistry, 273(47), 30921-30926.

Lacourciere, G. M., Mihara, H., Kurihara, T., Esaki, N., \& Stadtman, T. C. (2000). Escherichia coli NifS-like proteins provide selenium in the pathway for the biosynthesis of selenophosphate. Journal of Biological Chemistry, 275(31), 23769-23773.

Lampis, S., Zonaro, E., Bertolini, C., Cecconi, D., Monti, F., Micaroni, M., Turner, R. J., Butler, C. S., \& Vallini, G. (2017). Selenite biotransformation and detoxification by Stenotrophomonas maltophilia SeITE02: Novel clues on the route to bacterial biogenesis of selenium nanoparticles. Journal of Hazardous Materials, 324, 3-14

Lee, B. J., Worland, P. J., Davis, J. N., Stadtman, T. C., \& Hatfield, D. L. (1989). Identification of a selenocysteyl-tRNA (Ser) in mammalian cells that recognizes the nonsense codon, UGA. Journal of Biological Chemistry, 264(17), 9724-9727.

Leong-Morgenthaler, P., Oliver, S. G., Hottinger, H., \& Söll, D. (1994). A Lactobacillus nifS-like gene suppresses an Escherichia coli transaminase B mutation. Biochimie, 76(1), 45-49.

Li, X. Z., \& Nikaido, H. (2004). Efflux-mediated drug resistance in bacteria. Drugs, 64(2), 159-204.

Mehdi, Y., Homick, J. L., Istasse, L., \& Dufrasne, I. (2013). Selenium in the environment, metabolism and involvement in body functions. Molecules, 18(3), 3292-3311.

Mullins, L. S., Hong, S. B., Gibson, G. E., Walker, H., Stadtman, T. C., \& Raushel, F. M. (1997). Identification of a phosphorylated enzyme intermediate in the catalytic mechanism for selenophosphatesynthetase. Journal of the American Chemical Society, 119(28), 6684-6685.

Naito, M., Yokoyama, T., Hosokawa, K., \& Nogi, K. (Eds.). (2018). Nanoparticle Technology Handbook. Elsevier.

Nancharaiah, Y. V., \& Lens, P. N. L. (2015). Ecology and biotechnology of seleniumrespiring bacteria. Microbiology and Molecular Biology Reviews, 79(1), 61-80.

Nelersa, C. M., Schmier, B. J., \& Malhotra, A. (2011). Purification and crystallization of Bacillus subtilis NmA, a novel enzyme involved in nanoRNA degradation. Acta Crystallographica Section F: Structural Biology and Crystallization Communications, 67(10), 1235-1238. 
Newton, G. L., \& Fahey, R. C. (1989). Glutathione in prokaryotes. Glutathione: Metabolism and physiological functions. CRC Press, Boca Raton, Florida, 69-77.

Newton, G. L., Rawat, M., La Clair, J. J., Jothivasan, V. K., Budiarto, T., Hamilton, C. J., Claiborne, A., Helmann, J. D., \& Fahey, R. C. (2009). Bacillithiol is an antioxidant thiol produced in Bacilli. Nature Chemical Biology, 5(9), 625-627.

Oremland, R. S., Herbel, M. J., Blum, J. S., Langley, S., Beveridge, T. J., Ajayan, P. M., Sutto, T., Ellis, A. V., \& Curran, S. (2004). Structural and spectral features of selenium nanospheres produced by Se-respiring bacteria. Applied Environmental Microbiology, 70(1), 52-60.

Oudhia, A. (2012). UV-VIS spectroscopy as a nondestructive and effective characterization tool for II-VI compounds. Recent Research in Science and Technology, 4(8), 109-111.

Overschelde, O. V., Guisbiers, G., \& Snyders, R. (2013). Green synthesis of selenium nanoparticles by excimer pulsed laser ablation in water. APL Materials, 1,042114

Paige, A. J., Mccracken, V. J., Theodorakis, C., \& Lin, Z.-Q. (2015). Microbial accumulation and transformation of nanoscale elemental selenium particles. Journal of Environmental Indicators, 9, 23-24.

Palomo-Siguero, M., \& Madrid, Y. (2017). Exploring the behavior and metabolic transformations of SeNPs in exposed lactic acid bacteria. Effect of nanoparticles coating agent. International Journal of Molecular Sciences, 18(8), 1712.

Pantidos, N., \& Horsfall, L. E. (2014). Biological synthesis of metallic nanoparticles by bacteria, fungi and plants. Journal of Nanomedicine and Nanotechnology, 5(5), 233-242.

Pouri, S., Motamedi, H., Honary, S., \& Kazeminezhad, I. (2017). Biological synthesis of selenium nanoparticles and evaluation of their bioavailability. Brazilian Archives of Biology and Technology, 60, e17160452.

Rayman, M. P. (2004). The use of high-selenium yeast to raise selenium status: How does it measure up? British Journal of Nutrition, 92(4), 557-573.

Sargent, M. G. (1975). Control of cell length in Bacillus subtilis. Journal of Bacteriology, 123(1), 7-19.

Schrauzer, G. N. (2003). The nutritional significance, metabolism and toxicology of selenomethionine. Advances in Food and Nutrition Research, 47, 73-112.

Selim, N. A., Radwan, N. L., Youssef, S. F., Eldin, T. S., \& Elwafa, S. A. (2015). Effect of inclusion inorganic, organic or nano selenium forms in broiler diets on: Physiological, immunological and toxicity statuses of broiler chicks. International Journal of Poultry Science, 14(3), 144-155.

Shirsat, S., Kadam, A., Naushad, M., \& Mane, R. S. (2015). Selenium nanostructures: Microbial synthesis and applications. Royal Society of Chemistry Advances, 5(112), 92799-92811.

Singh, R., \& Whitesides, G. M. (1991). Selenols catalyze the interchange reactions of dithiols and disulfides in water. The Journal of Organic Chemistry, 56(24), 6931-6933.

Sohm, B., Immel, F., Bauda, P., \& Pagnout, C. (2015). Insight into the primary mode of action of $\mathrm{TiO}_{2}$ nanoparticles on Escherichia coli in the dark. Proteomics, 15(1), 98-113.

Stadtman, T. C. (1974). Selenium biochemistry: Proteins containing selenium are essential components of certain bacterial and mammalian enzyme systems. Science, 183(4128), 915-922.

Stolz, J. F., \& Oremland, R. S. (1999). Bacterial respiration of arsenic and selenium. FEMS Microbiology Reviews, 23(5), 615-627.
Stolz, J. F., Basu, P., Santini, J. M., \& Oremland, R. S. (2006). Arsenic and selenium in microbial metabolism. Annual Review of Microbiology, 60, 107-130.

Stolz, J., Basu, P., \& Oremland, R. (2002). Microbial transformation of elements: The case of arsenic and selenium. International Microbiology, 5(4), 201-207.

Sun, D., \& Setlow, P. (1993). Cloning, nucleotide sequence, and regulation of the Bacillus subtilis nadB gene and a nifS-like gene, both of which are essential for NAD biosynthesis. Journal of Bacteriology, 175(5), 1423-1432.

Tan, Y., Yao, R., Wang, R., Wang, D., Wang, G., \& Zheng, S. (2016). Reduction of selenite to $\mathrm{Se}(0)$ nanoparticles by filamentous bacterium Streptomyces $\mathrm{sp}$ ES2-5 isolated from a selenium mining soil. Microbial Cell Factories, 15(1), $157-166$.

Thill, A., Zeyons, O., Spalla, O., Chauvat, F., Rose, J., Auffan, M., \& Flank, A. M. (2006). Cytotoxicity of $\mathrm{CeO}_{2}$ nanoparticles for Escherichia coli. Physicochemical insight of the cytotoxicity mechanism. Environmental Science and Technology, 40(19), 6151-6156.

Tsekhmistrenko, O. S., Tsekhmistrenko, S. I., Bityutskyy, V. S., Melnichenko, O. M., \& Oleshko, O. A. (2018). Biomimetic and antioxidant activity of nanocrystalline cerium dioxide. World of Medicine and Biology, 14(63), 196-201.

Tsekhmistrenko, S. I., Bityutskyy, V. S., Tsekhmistrenko, O. S., Polishchuk, V. M. Polishchuk, S. A., Ponomarenko, N. V., Melnychenko, Y. O., \& Spivak, M. Y. (2018). Enzyme-like activity of nanomaterials. Regulatory Mechanisms in Biosystems, 9(3), 469-476.

Veres, Z., Kim, I. Y., Scholz, T. D., \& Stadtman, T. C. (1994). Selenophosphatesynthetase. Enzyme properties and catalytic reaction. Journal of Biological Chemistry, 269(14), 10597-10603.

Verma, A., Uzun, O., Hu, Y., Hu, Y., Han, H. S., Watson, N., Chen, S., \& Stellacci, F. (2008). Surface-structure-regulated cell-membrane penetration by monolayer-protected nanoparticles. Nature Materials, 7(7), 588-595.

Wadhwani, S. A., Shedbalkar, U. U., Singh, R., \& Chopade, B. A. (2016). Biogenic selenium nanoparticles: Current status and future prospects. Applied Microbiology and Biotechnology, 100(6), 2555-2566.

Wang, T., Yang, L., Zhang, B., \& Liu, J. (2010). Extracellular biosynthesis and transformation of selenium nanoparticles and application in $\mathrm{H}_{2} \mathrm{O}_{2}$ biosensor. Colloids and Surfaces B: Biointerfaces, 80(1), 94-102.

Yu, Q., Boyanov, M. I., Liu, J., Kemner, K. M., \& Fein, J. B. (2018). Adsorption of selenite onto Bacillus subtilis: The overlooked role of cell envelope sulfhydryl sites in the microbial conversion of Se (IV). Environmental Science and Technology, 52(18), 10400-10407.

Yuan, J., Palioura, S., Salazar, J. C., Su, D., O’Donoghue, P., Hohn, M. J., Cardoso, A. M., Whitman, W. B., \& Söll, D. (2006). RNA-dependent conversion of phosphoserine forms selenocysteine in eukaryotes and archaea. Proceedings of the National Academy of Sciences, 103(50), 18923-18927.

Zee, J., Patterson, S., Wiseman, S., \& Hecker, M. (2016). Is hepatic oxidative stress a main driver of dietary selenium toxicity in white sturgeon (Acipenser transmontanus)? Ecotoxicology and Environmental Safety, 133, 334-340.

Zinoni, F., Birkmann, A., Stadtman, T. C., \& Böck, A. (1986). Nucleotide sequence and expression of the selenocysteine-containing polypeptide of formate dehydrogenase (formate-hydrogen-lyase-linked) from Escherichia coli. Proceedings of the National Academy of Sciences, 83(13), 4650-4654. 